\title{
KmrA Multidrug Efflux Pump from Klebsiella pneumoniae
}

\author{
Wakano Ogawa, Motohiro Koterasawa, Teruo Kuroda, and Tomofusa Tsuchiya* \\ Department of Molecular Microbiology, Graduate School of Medicine, Dentistry and Pharmaceutical Sciences, Okayama \\ University; Tsushima, Okayama 700-8530, Japan. \\ Received November 9, 2005; accepted December 1, 2005; published online December 7, 2005
}

\begin{abstract}
We cloned a gene responsible for multidrug resistance from the chromosomal DNA of Klebsiella pneumoniae MGH78578 that showed multidrug resistance. We designated the gene $\mathrm{kmrA}$. The deduced amino acid sequence of KmrA was similar to that of SmvA that is responsible for methyl viologen-resistance in Salmonella enterica sv. Typhi and Typhimurium. Introduction of the cloned $\mathbf{k m r A}$ gene into drug-hypersensitive Escherichia coli KAM32 cells made them resistant to acriflavine, 4',6-diamidino-2-phenylindole (DAPI), Hoechst 33342, tetraphenylphosphonium chloride (TPPCI), methyl viologen and ethidium bromide. We observed elevated energy-dependent efflux of ethidium in $E$. coli cells carrying the $k m r A$ gene compared with control cells. We also cloned the $\operatorname{smv} A$ gene from $S$. enterica sv. Typhimurium LT2 and investigated the resistance pattern for several drugs. The pattern was similar between KmrA from $K$. pneumoniae and SmvA from $S$. enterica.
\end{abstract}

Key words multidrug efflux pump; KmrA; SmvA; Klebsiella pneumoniae; Salmonella enterica

Klebsiella pneumoniae is one of the major causes of respiratory infection. It causes nosocomial infections in immunocompromised hosts. ${ }^{1)}$ Recent studies indicate that an increasing percentage of Klebsiella strains are becoming resistant to multiple antimicrobial agents. ${ }^{2)}$ In particular, infection with $K$. pneumoniae that are resistant against the $\beta$-lactams and fluoroquinolones are especially severe clinical problems. Furthermore, such resistant $K$. pneumoniae are often resistant against other multiple antimicrobial agents of unrelated structures. Multidrug efflux pumps are often involved in such multiple resistances. Multidrug efflux pumps in Escherichia coli, a bacterium closely related to $K$. pneumoniae, are well analyzed and characterized. ${ }^{3-8)}$ It has been reported that 38 genes or operons for multidrug efflux pumps would be present in the chromosome of E. coli. ${ }^{9)}$ In fact, 19 of them have been reported to be involved in drug resistance. ${ }^{6,10)}$ Thirtyfour genes or operons that code for multidrug efflux pumps have been suggested in the chromosome of Pseudomonas aeruginosa. $^{11)}$ Disruption of genes for multidrug efflux pumps resulted in a great decrease in the resistance against multiple antimicrobial agents in $E$. coli ${ }^{12,13)}$ and $P$. aeruginosa. ${ }^{14,15)}$ These results support the idea that multidrug efflux pumps are very important for the bacterial escape from the toxicity of many antimicrobial agents. So far, multidrug efflux pumps have not been well investigated for $K$. pneumoniae. Only two multidrug efflux pumps, AcrAB and QacE (including $\Delta \mathrm{QacE}$ ), have been reported with $K$. pneumoniae (A. Domenech-Sanchez, S. Alberti, L. Martinez-Martinez, A. Pascual, I. Gar-cia, and V. J. Benedi, Abstr. 41st Intersci. Conf. Antimicrob. Agents Chemother. abstr. C1-2018, p. 104, 2001). ${ }^{16)}$ Recently, the sequencing of the whole genome of $K$. pneumoniae strain MGH78578 was completed (http://genomeold.wustl.edu/projects/bacterial/kpneumoniae/). Based on the sequences, we estimated that there would be more than 30 genes or operons for multidrug efflux pumps in the chromosome of $K$. pneumoniae. We have been trying to clone many of such genes or operons, and in fact cloned more than 10 genes or operons responsible for multidrug resistance. ${ }^{17)} \mathrm{We}$ found that one of the genes, designated $k m r A$, coded for a multidrug efflux pump. Here we characterized the KmrA pump. We also cloned a gene for its homologue from Salmonella enterica, and characterized the pump.

\section{MATERIALS AND METHODS}

Bacterial Strains and Medium $K$. pneumoniae MGH78578 and $S$. enterica sv. Typhimurium LT2 were used as sources of chromosomal DNA. E. coli KAM32 lacking $a c r B$ and $y d h E^{18)}$ was used as a host. Cells were grown in $\mathrm{L}$ medium ( $1 \%$ polypeptone, $0.5 \%$ yeast extract and $0.5 \%$ $\mathrm{NaCl}, \mathrm{pH} 7.0$ ) under aerobic conditions at $37^{\circ} \mathrm{C}$.

Gene Cloning and Sub-cloning We previously reported the construction of many recombinant plasmids that carried DNA fragments from the chromosome of $K$. pneumoniae MGH78578 and which conferred elevated resistance against multiple antimicrobial agents in the drug-hypersusceptible $E$. coli KAM32 strain. ${ }^{17)}$ One of these plasmids (belonging to group 4 described in ref. 17), which conferred elevated resistance against ethidium bromide, norfloxacin, 4',6-diamidino-2-phenylindole (DAPI), Hoechst 33342, tetraphenylphosphonium chloride (TPPCl), was designated as pESK13. A $1.83 \mathrm{kbp} \mathrm{KpnI} \mathrm{fragment} \mathrm{from} \mathrm{pESK13} \mathrm{was} \mathrm{sub-}$ cloned using plasmid pSTV28 (TaKaRa. Co) as a vector, and a resulting hybrid plasmid was designated as pNTV224. The pNTV224 plasmid conferred multidrug resistance to $E$. coli KAM32. We determined nucleotide sequence of both ends of the DNA insert by the dideoxy chain termination method, ${ }^{19)}$ and compared the sequence with the available genome sequence of $K$. pneumoniae MGH78578 (http://genomeold. wustl.edu/projects/bacterial/kpneumoniae/). We found that there was one open reading frame in the region of the DNA insert of pNTV224, which was responsible for the multidrug resistance, and designated it as $k m r A$ (klebsiella multidrug resistance). The $k m r A$ gene was located in the opposite direction from the lac promoter in pNTV224. Thus, $k m r A$ is expressed from its original promoter.

We cloned the $s m v A$ gene of $S$. enterica by the PCR method. $^{20)}$ The primer pairs used were; 5'-TCATATTGGTACCACATTAGCCAATGCGCG-3' and 5'-TCAGGTACCAAGAGGTTGAGGAAATGGAC-3'. The primers were designed such that the amplified DNA fragment contained 
the promoter region and the $s m v A$ gene. Genomic DNA prepared from $S$. enterica sv. Typhimurium LT2 was used as the template. The PCR conditions were as follows: initial denaturation for $4 \mathrm{~min}$ at $95^{\circ} \mathrm{C}$ followed by 35 cycles of $1 \mathrm{~min}$ at $95^{\circ} \mathrm{C}, 1 \mathrm{~min}$ at $59^{\circ} \mathrm{C}, 2 \mathrm{~min} 30 \mathrm{~s}$ at $68^{\circ} \mathrm{C}$. The amplified PCR fragment was digested with endonuclease $K p n I$ and ligated to the KpnI site of the vector pSTV28. E. coli KAM32 was used as the host, and the transformants were selected on $\mathrm{L}$ plates containing $20 \mu \mathrm{g} / \mathrm{ml}$ of chloramphenicol, 0.1 $\mathrm{mm}$ isopropyl- $\beta$-D-thiogalactopyranoside and $100 \mu \mathrm{g} / \mathrm{ml}$ of 5-bromo-4-chloro-3-indolyl- $\beta$-galactopyranoside at $37^{\circ} \mathrm{C}$. Twelve white colonies were picked up, and three of them were found to harbor recombinant plasmid carrying the $s m v A$ gene. We designated one of the recombinant plasmids as pSMVA3.

Drug Susceptibility Testing The minimum inhibitory concentrations (MICs) of various antimicrobial agents were determined in Mueller-Hinton broth (Difco, Sparks, U.S.A.) by the two-fold dilution method. ${ }^{21)}$ Cells in the test medium $\left(10^{5}\right.$ cells $\left./ \mathrm{ml}\right)$ were incubated at $37^{\circ} \mathrm{C}$ for $24 \mathrm{~h}$, and the growth was subsequently judged by eye inspection.

Ethidium Transport Assay E. coli cells harboring each plasmid were grown in L broth supplemented with $40 \mathrm{~mm}$ potassium lactate until the exponential phase of growth was reached. The harvested cells were washed with modified Tanaka medium $\left(\mathrm{Na}^{+}\right.$salts of the original medium were replaced with $\mathrm{K}^{+}$salts) ${ }^{22)}$ and suspended in the same medium. Potassium lactate (final concentration, $40 \mathrm{~mm}$ ) was added to the cell suspension, and the cell suspension was kept at $37^{\circ} \mathrm{C}$ for $5 \mathrm{~min}$ with stirring. Ethidium bromide was added at 20 $\mu \mathrm{M}$ to the cell suspension to initiate the assay. Carbonyl cyanide m-chlorophenylhydrazone (CCCP) was added at 100 $\mu \mathrm{M}$ where indicated. The fluorescence change in the assay mixture was monitored with excitation and emission wavelengths of $500 \mathrm{~nm}$ and $580 \mathrm{~nm}$, respectively.

Reverse Transcription (RT)-Polymerase Chain Reaction (PCR) Analysis Cells of $K$. pneumoniae were harvested at the exponential phase of growth. Total cellular RNA was extracted from the cells using the Qiagen RNeasy Mini Kit (Qiagen Inc., U.S.A.). Cell lysate was passed through the QIAshredder column before being applied onto the RNeasy column. Samples loaded to the RNeasy column were treated with RNase-Free DNase (Qiagen Inc., U.S.A.), according to the manufacturer's protocol. A $1 \mathrm{ng}$ sample of total RNA was used as the template for RT-PCR with the OneStep RT-PCR Kit (Qiagen Inc., U.S.A.) according to the manufacturer's protocol. Primers used for $k m r A$ were $5^{\prime}$ TATTCCGGTGGCGATTGACGC-3' and 5'-ATTGCTCTGCTGCGCCGTTG-3'. After amplification, the reaction product was analyzed by Agarose X (3\% w/v) (Wako Pure Chemicals) gel electrophoresis.

\section{RESULTS AND DISCUSSION}

Changes in MICs of Drugs Due to KmrA or SmvA We measured the MICs of various antimicrobial agents in $E$. coli cells carrying or not-carrying the $k m r A$ gene. As shown in Table 1, E. coli KAM32/pNTV224 carrying the kmrA gene showed elevated MICs of kanamycin, norfloxacin, acriflavine, ethidium bromide, methylviologen, tetraphenylphosphonium chloride (TPPCl), and so on, compared with control
Table 1. MICs of Various Antimicrobial Agents

\begin{tabular}{|c|c|c|c|}
\hline \multirow[b]{2}{*}{$\begin{array}{l}\text { Antimicrobial } \\
\text { agents }\end{array}$} & \multicolumn{3}{|c|}{$\operatorname{MICs}(\mu \mathrm{g} / \mathrm{ml})$} \\
\hline & $\begin{array}{l}\text { E. coli KAM32/ } \\
\text { pSTV28 } \\
\text { (control) }\end{array}$ & $\begin{array}{c}\text { E. coli KAM32/ } \\
\text { pNTV224 } \\
\text { (carrying } k m r A \text { ) }\end{array}$ & $\begin{array}{c}\text { E. coli KAM32/ } \\
\text { pSMVA3 } \\
\text { (carrying } s m v A \text { ) }\end{array}$ \\
\hline Kanamycin & 1 & 4 & 1 \\
\hline Gentamicin & 0.25 & 1 & 0.25 \\
\hline Erythromycin & 4 & 8 & 8 \\
\hline Tetracycline & 0.5 & 0.5 & 2 \\
\hline Nalidixic acid & 1 & 1 & 1 \\
\hline Norfloxacin & 0.03 & 0.25 & 0.125 \\
\hline Ofloxacin & 0.015 & 0.03 & 0.03 \\
\hline Cefmetazole & 0.5 & 0.5 & 1 \\
\hline Acriflavine & 4 & 128 & 128 \\
\hline Benzalkonium $\mathrm{Cl}$ & 4 & 4 & 8 \\
\hline CTAB & 8 & 32 & 32 \\
\hline $\mathrm{EtBr}$ & 4 & 64 & 256 \\
\hline Hoechst 33342 & 0.5 & 4 & 4 \\
\hline Methylene blue & 64 & 64 & 64 \\
\hline Methyl viologen & 64 & $>1024$ & $>1024$ \\
\hline Quinacrine & 64 & 64 & 64 \\
\hline Rhodamine $6 \mathrm{G}$ & 8 & 8 & 8 \\
\hline TPPCl & 8 & 512 & 512 \\
\hline
\end{tabular}

E. coli $\mathrm{KAM} 32 / \mathrm{pSTV} 28$. Thus, it seems that the $k m r A$ gene codes for a multidrug efflux pump with high extrusion activity and wide substrate specificity. Previously we reported that K. pneumoniae MGH78578 showed much higher MICs of many antimicrobial agents compared with the ATCC10031 strain. ${ }^{17)}$ We cloned many other genes responsible for multidrug resistance from the chromosomal DNA of MGH78578 ${ }^{17)}$ in addition to $k m r A$. Thus, it seems that other multidrug efflux pumps including AcrAB are also responsible for multidrug resistance in MGH78578.

We found several proteins and putative proteins that showed sequence similarity with $\mathrm{KmrA}$ in the Swiss-Prot database, as described below. SmvA of S. enterica Sv. Typhimurium showed the highest identity and similarity with $\mathrm{KmrA}$. It has been reported that SmvA is involved in resistance against methyl viologen ${ }^{23}$ and acriflavine. ${ }^{24)}$ We cloned the $s m v A$ gene, introduced it into cells of the drug-hypersusceptible $E$. coli KAM32 host, and measured the MICs of various antimicrobial agents. E. coli KAM32/pSMVA3 (carrying $s m v A$ ) showed elevated MICs of tetracycline, norfloxacin, acriflavine, ethidium bromide, methyl viologen, TPPCl and so on, compared with E. coli KAM32/pSTV28 (control) (Table 1). Thus, SmvA made the drug-hypersusceptible cells much more resistant against multiple antimicrobial agents. The substrate specificities in KmrA and SmvA were similar, although some differences were observed. For example, kanamycin and gentamicin were substrates for KmrA, but not for SmvA; and tetracycline was a substrate for SmvA, but not for KmrA.

Ethidium Efflux Activity We tested the efflux activities of both KmrA and SmvA by measuring changes in the intracellular accumulation levels of ethidium under energized and deenergized conditions. We observed a lower intracellular level of ethidium (higher ethidium efflux activity) with cells of $E$. coli KAM32/pNTV224 possessing KmrA than with cells of $E$. coli KAM32/pSTV28 (control) under energized conditions (Fig. 1A). The intracellular ethidium levels reached the same plateau after the addition of a proton con- 
ductor CCCP in the two types of cells. We also observed a lower intracellular level of ethidium (higher ethidium efflux activity) with cells of $E$. coli KAM32/pSMVA3 possessing SmvA than with cells of E. coli KAM32/pSTV28 (control) under energized conditions (Fig. 1B). Again, the intracellular ethidium levels reached the same plateau after the addition of CCCP in the two types of cells. Thus, we conclude that both KmrA and SmvA are energy-dependent drug efflux pumps.

Family of the Transporter Judging from the nucleotide sequence (http://genomeold.wustl.edu/projects/bacterial/kpneumoniae/), it seems that KmrA consists of 499 amino acid residues. The hydropathy pattern of KmrA suggests the presence of 14 hydrophobic regions that seem to be transmembrane domains. A Blast search ${ }^{25}$ ) revealed that $\mathrm{KmrA}$ showed sequence similarity not only with SmvA but also with QacB of Staphylococcus aureus and EmrB of E. coli and other putative pumps belonging to the major facilitator (MF) superfamily $^{26)}$ (Table 2). Their sequence identities and similarities were $75 \%$ and $94 \%$ with SmvA, 33\% and 75\% with QacB, and $24 \%$ and $66 \%$ with EmrB, respectively. Thus, it is clear that KmrA belongs to the multidrug efflux pumps of the MF superfamily. ${ }^{24)}$ Proteins or hypothetical proteins that showed sequence similarity with $\mathrm{KmrA}$ are widely distributed in both Gram-negative and Gram-positive bacteria (Swiss-Prot database) including Erwinia, Pseudomonas, Streptococcus, Streptomyces, Mycobacterium, Nocardia and Corynebacterium. Among these bacterial genera, it seemed that many similar proteins (or hypothetical proteins) are present in Streptomyces (data not shown). Bacteria belonging to Streptomyces produce many antibiotics. Thus, KmrA-like proteins in Streptomyces might be related to extrusion systems for antibiotics.

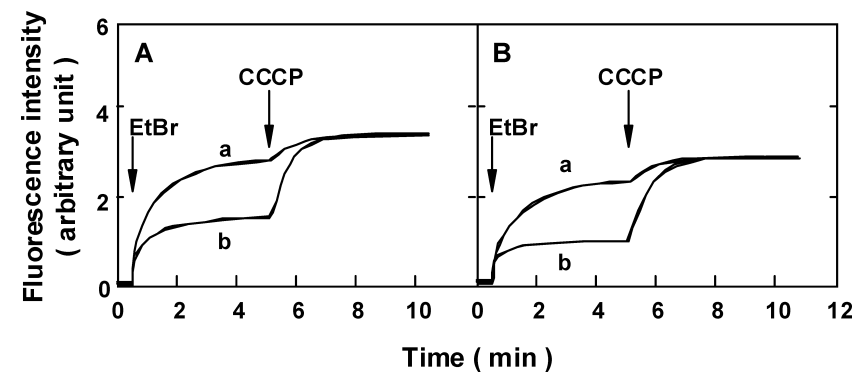

Fig. 1. Transport of Ethidium in Cells

Cells were incubated in a medium, and ethidium transport was monitored continuously by measuring the fluorescence intensity of ethidium. Ethidium bromide (EtBr) (final concentration, $20 \mu \mathrm{M}$ ) was added to the assay mixture to initiate the assay at the time point indicated by the first downward arrow, and CCCP (final concentration, 100 $\mu \mathrm{M})$ was added at the time point indicated by the second downward arrow to de-energize the cells. Panel A, E. coli KAM32/pSTV28 (a) and E. coli KAM32/pNTV224 (b); Panel B, E. coli KAM32/pSTV28 (a) and E. coli KAM32/pSMVA3 (b).

Table 2. Sequence Identity and Similarity of KmrA with Others
Expression of $\boldsymbol{k m} \boldsymbol{A}$ in $\boldsymbol{K}$. pneumoniae We investigated whether $k m r A$ is expressed in cells of $K$. pneumoniae MGH78578 by the RT-PCR method. We observed a band corresponding to $k m r A$ (data not shown). No corresponding band was detected in an RT-negative control sample. Thus, it is clear that $k m r A$ is expressed constitutively in the MGH78578 strain, and it is likely that $\mathrm{KmrA}$ is a functional multidrug efflux pump in cells of $K$. pneumoniae MKG78578. We tested whether drugs that are substrates for KmrA enhance the expression of $k m r A$. However, enhanced expression was not observed when cells were grown in the presence of sub-MIC levels of drugs (data not shown).

Acknowledgments We thank Dr. Manuel Varela of Eastern New Mexico University for critically reading the manuscript. This research was supported in part by a Grant-in-Aid for Scientific Research from the Ministry of Education, Culture, Sports, Science and Technology of Japan.

\section{REFERENCES}

1) Podschun R., Ullmann U., Clin. Microbiol. Rev., 11, 589-603 (1998).

2) Brisse S., Milatovic D., Fluit A. C., Verhoef J., Schmitz F. J., Eur. J. Clin. Microbiol. Infect. Dis., 19, 64-68 (2000).

3) Edgar R., Bibi E., J. Bacteriol., 179, 2274-2280 (1997).

4) Mine T., Morita Y., Kataoka A., Mizushima T., Tsuchiya T., J. Biochem. (Tokyo), 124, 187-193 (1998).

5) Nagakubo S., Nishino K., Hirata T., Yamaguchi A., J. Bacteriol., 184, 4161-4167 (2002).

6) Nishino K., Yamaguchi A., J. Bacteriol., 183, 5803-5812 (2001).

7) Ramos J. L., Duque E., Gallegos M. T., Godoy P., Ramos-Gonzalez M. I., Rojas A., Teran W., Segura A., Annu. Rev. Microbiol., 56, 743-768 (2002).

8) Yu E. W., Aires J. R., Nikaido H., J. Bacteriol., 185, 5657-5664 (2003).

9) Blattner F. R., Plunkett G., 3rd, Bloch C. A., Perna N. T., Burland V., Riley M., Collado-Vides J., Glasner J. D., Rode C. K., Mayhew G. Gregor F., J., Davis N. W., Kirkpatrick H. A., Goeden M. A., Rose D. J., Mau B., Shao Y., Science, 277, 1453-1474 (1997).

10) Chung Y. J., Saier M. H., Jr., J. Bacteriol., 184, 2543-2545 (2002).

11) Stover C. K., Pham X. Q., Erwin A. L., Mizoguchi S. D., Warrener P., Hickey M. J., Brinkman F. S., Hufnagle W. O., Kowalik D. J., Lagrou M., Garber R. L., Goltry L., Tolentino E., Westbrock-Wadman S., Yuan Y., Brody L. L., Coulter S. N., Folger K. R., Kas A., Larbig K., Lim R., Smith K., Spencer D., Wong G. K., Wu Z., Paulsen I. T., Reizer J., Saier M. H., Hancock R. E., Lory S., Olson M. V., Nature (London), 406, 959-964 (2000).

12) Fralick J. A., J. Bacteriol., 178, 5803-5805 (1996).

13) Okusu H., Ma D., Nikaido H., J. Bacteriol., 178, 306-308 (1996).

14) Masuda N., Sakagawa E., Ohya S., Gotoh N., Tsujimoto H., Nishino T., Antimicrob. Agents Chemother, 44, 3322-3327 (2000).

15) Morita Y., Komori Y., Mima T., Kuroda T., Mizushima T., Tsuchiya T., FEMS Microbiol. Lett., 202, 139-143 (2001).

16) Paulsen I. T., Littlejohn T. G., Radstrom P., Sundstrom L., Skold O., Swedberg G., Skurray R. A., Antimicrob. Agents Chemother, 37,

\begin{tabular}{|c|c|c|c|c|}
\hline Organism & $\begin{array}{c}\text { Protein } \\
\text { (Accession No.) }\end{array}$ & $\begin{array}{l}\text { Amino acid residues } \\
\text { (Compared residues) }\end{array}$ & $\begin{array}{l}\text { Identity } \\
(\%)\end{array}$ & $\begin{array}{l}\text { Similarity } \\
(\%)\end{array}$ \\
\hline Klebsiella pneumoniae & $\mathrm{KmrA}$ & 499 & & \\
\hline Salmonella enterica & SmvA (NP_460533) & 495 (494) & 75 & 94 \\
\hline Streptomyces coelicolor & LfrA (NP_ 733586$)$ & $504(484)$ & 34 & 78 \\
\hline Staphylococcus aureus & QacB (AAQ10694) & $514(489)$ & 33 & 75 \\
\hline Staphylococcus aureus & QacA (CAA39963) & $514(489)$ & 32 & 66 \\
\hline Streptomyces cinnamonensis & MonT (AAO65793) & $511(492)$ & 31 & 73 \\
\hline Streptomyces virginiae & VarS (BAA78678) & $518(509)$ & 30 & 69 \\
\hline Escherichia coli & EmrB (NP_460533) & $512(506)$ & 24 & 66 \\
\hline
\end{tabular}




$$
\text { 761-768 (1993). }
$$

17) Ogawa W., Li D. W., Yu P., Begum A., Mizushima T., Kuroda T., Tsuchiya T., Biol. Pharm. Bull., 28, 1505-1508 (2005).

18) Chen J., Morita Y., Huda M. N., Kuroda T., Mizushima T., Tsuchiya T., J. Bacteriol., 184, 572-576 (2002).

19) Sanger F., Nicklen S., Coulson A. R., Proc. Natl. Acad. Sci. U.S.A., 74, 5463-5467 (1977).

20) Saiki R. K., Gelfand D. H., Stoffel S., Scharf S. J., Higuchi R., Horn G. T., Mullis K. B., Erlich H. A., Science, 239, 487-491 (1988).

21) Japan Society of Chemotherapy, Chemotherapy (Tokyo), 38, 103-105 (1990).
22) Tanaka S., Lerner S. A., Lin E. C., J. Bacteriol., 93, 642-648 (1967).

23) Hongo E., Morimyo M., Mita K., Machida I., Hama-Inaba H., Tsuji H., Ichimura S., Noda Y., Gene, 148, 173-174 (1994).

24) Santiviago C. A., Fuentes J. A., Bueno S. M., Trombert A. N., Hildago A. A., Socias L. T., Youderian P., Mora G. C., Mol. Microbiol., 46, 687-698 (2002)

25) McGinnis S., Madden T. L., Nucleic. Acids Res., 32, W20-W25 (2004).

26) Paulsen I. T., Brown M. H., Skurray R. A., Microbiol. Rev, 60, 575608 (1996). 